\title{
Effect of Water Hardness and pH Value on the Corrosion Behaviour of Copper in an Emulsion
}

\author{
Xudong Yan, Jianlin Sun ${ }^{*}$ \\ School of Materials Science and Engineering, University of Science and Technology Beijing, Beijing \\ 100083, China \\ E-mail: sj1@ustb.edu.cn
}

doi: $10.20964 / 2017.12 .43$

Received: 19 July 2017 / Accepted: 6 October 2017 / Published: 12 November 2017

\begin{abstract}
Hard tap water and soft water were used to prepare oil-in-water $(\mathrm{O} / \mathrm{W})$ emulsions separately. The effects of water hardness and emulsion $\mathrm{pH}(2.5,4.8,8.3$, and 12.1) on the corrosion behaviour of copper in an emulsion were investigated using potentiodynamic (PD) polarization curves, electrochemical impedance spectroscopy (EIS) and open circuit potential (OCP). The surface morphology of the $\mathrm{Cu}$ electrodes and the attachment of corrosive products were analysed by scanning electron microscopy (SEM) and energy dispersive spectrometry (EDS), respectively. The results showed that without an inhibitor, the corrosion current density of hard tap water increased by $1.6 \times 10^{-}$ ${ }^{3} \mathrm{~A} / \mathrm{cm}^{2}$, and the electrochemical resistances were significantly reduced compared with those in soft water, resulting in the disruption of the passive layer and accelerating corrosion. The corrosivity order of the four emulsions with different $\mathrm{pH}$ values was found to be strong acid $(\mathrm{pH}=2.5)>$ strong alkali $(\mathrm{pH}=12.1)>$ weak acid $(\mathrm{pH}=4.8)>$ weak alkali $(\mathrm{pH}=8.3)$. For strong acid/alkali emulsion systems, copper is more likely to react with chloride ions and oxygen ions to generate pitting corrosion.
\end{abstract}

Keywords: Corrosion, Soft water, Electrochemical impedance spectroscopy, Alkali, Acid

\section{FULL TEXT}

(C) 2017 The Authors. Published by ESG (www.electrochemsci.org). This article is an open access article distributed under the terms and conditions of the Creative Commons Attribution license (http://creativecommons.org/licenses/by/4.0/). 